\title{
Molecular detection of human enteric viruses circulating among children with acute gastroenteritis in Valencia, Venezuela, before rotavirus vaccine implementation
}

\author{
Ana C. Alcalá ${ }^{1,4}$, Kriss Pérez ${ }^{1}$, Ruth Blanco ${ }^{1}$, Rosabel González ${ }^{3}$, Juan E. Ludert ${ }^{2}$, Ferdinando Liprandi ${ }^{1}$ \\ and Esmeralda Vizzi ${ }^{{ }^{*}}$ (1)
}

\begin{abstract}
Background: The role of rotavirus as main etiologic agent of diarrhea has been well documented worldwide, including in Venezuela. However, information about the prevalence of gastrointestinal viruses such as calicivirus, adenovirus and astrovirus is limited and the contribution of other agents as Aichi virus and klassevirus is largely unknown. To explore the etiological spectrum of diarrhea associated with agents other than rotaviruses, 227 stool samples from children under 5 years old with acute gastroenteritis, collected in Valencia (Venezuela) from 2001 to 2005, and previously tested as rotavirus-negative, were analyzed for caliciviruses, adenoviruses, astroviruses, Aichi viruses, klasseviruses, picobirnaviruses and enteroviruses by specific RT-PCRs.
\end{abstract}

Results: At least one viral agent was detected in 134 (59\%) of the samples analyzed, mainly from children under 24 months of age and most of them belonging to the lowest socioeconomic status. Overall, enterovirus was identified as the most common viral agent (37.9\%), followed by calicivirus (23.3\%), adenovirus (11.5\%), astrovirus (3.5\%), klassevirus (1.3\%) and Aichi virus (0.4\%), while no picobirnavirus was detected. Klasseviruses were found during 2004 and 2005 and Aichi viruses only in 2005, indicating their circulation in Venezuela; meanwhile, the rest of the viruses were detected during the whole study period. Coinfections with two or more viruses were found in 39 (29.1\%) of the infected children, most under 24 months of age. Adenovirus was involved as the coinfecting agent in at least $46.9 \%$ of the cases, but no differences concerning socio-demographic variables were observed between the coinfected and the single infected children.

Conclusions: The results show that various enteric viruses, including enteroviruses, caliciviruses and adenoviruses, accounted for a significant proportion of infantile diarrhea cases in Venezuela before rotavirus vaccine implementation. In addition, emerging viruses as Aichi virus and klassevirus were found, indicating the need to continue monitoring their spreading into the communities. Efforts are needed to develop more accurate methods to identify the major causes of diarrhea and to provide tools for more effective preventive measures.

Keywords: Acute gastroenteritis, Children, Enteric viruses, Prevalence, Venezuela

\footnotetext{
*Correspondence: esmeralda.vizzi@gmail.com

${ }^{1}$ Laboratorio de Biología de Virus, Centro de Microbiología y Biología

Celular, Instituto Venezolano de Investigaciones Científicas (IVIC), Apdo.

21827, Caracas 1020, Venezuela

Full list of author information is available at the end of the article
} 


\section{Background}

Acute gastroenteritis (AGE) in children is one of the most significant diseases, causing morbidity and mortality worldwide $[1,2]$. Although the improvement in sanitation and prevention strategies has determined a substantial reduction in the mortality rate for diarrhea from $15 \%$ in 2008 , to about $9 \%$ in 2015 , equivalent to 500,000 deaths among children less than 5 years old, infectious diarrheas are still an important public health concern, both in resource-poor settings and industrialized countries $[2,3]$.

Viruses are recognized as a major cause of severe AGE, particularly in children. Rotaviruses (RV) are the main cause of mortality due to diarrhea in those under 5 years old, preventable with the vaccination $[4,5]$. Yet, despite a significant reduction after $R V$ vaccine introduction in 2006, hospitalizations for infantile AGE of viral etiology continued to be reported [6-9]. The increasing use of more powerful diagnostic systems in the last few years, as the conventional polymerase chain reaction (PCR) or high-throughput technologies, for the amplification and identification of virus genomes in stool samples, has resized the study of the agents involved in childhood AGE $[7,10,11]$, and changed significantly the pathogen spectrum of community-acquired gastroenteritis $[6,7$, $12,13]$.

Other viruses considered of clinical importance and frequently associated with diarrhea mortality are the human caliciviruses $(\mathrm{HuCVs})$, members of the family Caliciviridae, which have acquired importance, especially after RV vaccine implementation [6, 10, 14]. Human adenoviruses (HAdVs), members of the family Adenoviridae, are often reported as the second or third cause of infantile diarrhea, both sporadic or outbreak associated, and cause a wide range of disease symptoms $[14,15]$. Finally, human astroviruses (HAstVs), of the family Astroviridae, which affect predominantly children under 2 years of age, have been involved in $0.5-15 \%$ of diarrheal outbreaks associated to severe pediatric cases [16-18].

On the other hand, the clinical importance of viruses belonging to the wide family Picornaviridae, such as enterovirus (EV), Aichi virus (AiV) and klassevirus/salivirus (KV), is up-to-date unclear, with those viruses presumably playing a rather minor epidemiological role in diarrhea [14, 19-22]. Some subgroups of EVs have been involved as causative of at least 3.4\% of AGE of unknown etiology [23]. Similarly, AiV, of the genus Kobuvirus, was initially described as cause of oyster-associated nonbacterial gastroenteritis in human [22], and later associated with AGE, reaching detection rates between 0.5 and $0.9 \%$ in Europe, and up to $4 \%$ in Asia and Africa [20, 24]. AiVs were recovered during a study from a major river polluted with sewage discharges in Caracas (Venezuela) during 2007-2008 [25], but its impact on the burden of AGE in Venezuela is unknown. Finally, KVs, discovered in human stool and sewage [22], have been significantly associated with pediatric diarrhea in different countries, especially in children less than 3 years old, with a frequency ranging from 0.1 to $8.7 \%$ [26-28].

Because the information about viruses different from $\mathrm{RV}$ associated with diarrhea in Venezuela is limited, the present study was aimed to determine the incidence of infections caused by other conventional gastroenteritis viruses before $\mathrm{RV}$ vaccine implementation, and to investigate the contribution of AiV and KV to diarrheal diseases, until now unknown in Venezuela. For this purpose, children less than 5 years old with diarrhea attended at a large public hospital in Valencia City, over a 5-year period (2001-2005), were studied using molecular detection assays.

\section{Methods \\ Study design}

The study included stool samples collected from children with AGE under 5 years old, attended during the years 2001-2005 in the city of Valencia, Carabobo State (Venezuela), as part of a RV diarrhea surveillance program conducted at the Hospital de Niños "Dr. Jorge Lizarraga" of the Ciudad Hospitalaria "Dr. Enrique Tejera" (CHET) described previously [29].

AGE was defined as three or more liquid stools over a 24-h period and for not over 14 days. To determine the epidemiologic and clinical characteristics of the AGE, information from the clinical history and the physical examination were collected: age, gender, nutritional status and type of treatment (outpatient or inpatient hospital based) were recorded for each case and used as measurement instrument for the severity of the community-acquired AGE, together with the estimation of dehydration, assessed according to WHO criteria [30]. Inpatient treatment was defined as the admission to either the emergency room for a short stay to receive oral rehydration therapy $(<24 \mathrm{~h})$ or to the regular pediatric wards of the hospital for longer time [31]. The socioeconomic status was determined by a modified Graffar methodology [32].

\section{Sample collection}

From a total of 13,026 fecal diarrhea specimens obtained from the enrolled children within $48 \mathrm{~h}$ following admission, 227 were randomly selected from RV negativetested samples. All the samples had been systematically examined for the presence of RV antigen, bacteria and parasites as previously described $[29,33]$ and resulted negative for all of them. All samples were stored at $-80^{\circ} \mathrm{C}$ until processed. 


\section{Nucleic acid extraction}

Fecal suspensions (10\% w/v in phosphate buffer saline) were prepared from each stool sample, vortexed, and clarified by centrifugation at $10,000 \mathrm{~g}$ for $10 \mathrm{~min}$. Viral RNA/DNA was extracted simultaneously from $200 \mu \mathrm{l}$ of supernatant, using the QIAamp MinElute Virus Spin Kit (QIAGEN, Hilden, Germany), based in a spin-column procedure, and following the manufacturer's instructions. Briefly, samples were lysed in the presence of QIAGEN Protease and Buffer AL containing RNA carrier provided by the kit. Ethanol absolute (Merck, KGaA, Darmstadt, Germany) was added to the sample that was then transferred onto a QIAamp MinElute column, where the viral nucleic acids were adsorbed onto the silica-gel membrane. Wash buffers were used to remove impurities by centrifugation, and finally, the viral nucleic acids were eluted in $50 \mu \mathrm{l}$ of Buffer AVE (provided), for use in amplification reactions or storage at $-70{ }^{\circ} \mathrm{C}$.

\section{Reverse transcription (RT)}

Screening for the presence of RNA viruses, such as $\mathrm{HuCV}, \mathrm{HAstV}, \mathrm{AiV}, \mathrm{KV}, \mathrm{EV}$ and human picobirnavirus (HPBV), was conducted firstly by RT reaction, as follows: the extracted RNA was denatured and then reverse transcribed with random primers $(0.02 \mu \mathrm{g})$ using M-MLV reverse transcriptase $(200 \mathrm{U})$ and deoxynucleoside triphosphate mix $(0.2 \mathrm{mM})$, RNasin (40 U) (Invitrogen, Carlsbad, California, USA) in reverse transcription buffer to a final volume of $50 \mu$ l. The mixture was incubated at $37^{\circ} \mathrm{C}$ for $1 \mathrm{~h}$ followed by incubation at $70{ }^{\circ} \mathrm{C}$ for $15 \mathrm{~min}$, to obtain cDNA.

\section{Polymerase chain reaction (PCR)}

Single PCR reactions were performed from $5 \mu \mathrm{l}$ of extracted DNA (for HAdV detection), or cDNA (for RNA viruses), using a selected combination of oligonucleotide primers specific for each virus previously described $[22,34-40]$ at a final concentration of $0.2 \mu \mathrm{M}$ each one. Two additional degenerated primers were designed for this study by multiple alignments, leading to broad target specificity for HuCV (290YM) and HAstV (MON394d) (Table 1). Cycling conditions used were adapted as shown in Table 1. All PCR reactions were done in a final volume of $50 \mu \mathrm{l}$ and the PCR products were analyzed by agarose gel electrophoresis and ethidium bromide staining.

\section{Statistical analysis}

Data were analysed for the comparisons of variables using $2 \times 2$ tables with $\chi^{2}$ test, or Fisher's exact test (twotailed, 95\% confidence intervals) (Epi Info ${ }^{\mathrm{TM}}$ 7.1.4.0, CDC Atlanta, GA, USA). Student's test was applied for comparisons of variable values. Tests were considered significant when $\mathrm{p}<0.05$.

\section{Results}

Prevalence of the viral infections

Overall, the analysis by RT-PCR for HuCV, HAdV, HAstV, AiV, KV, EV and HPBV of the 227 selected stool samples negative for RV, enteropathogenic bacteria and parasitic infections, revealed the presence of at least one viral agent in 134 (59\%) of them. The annual prevalence of viral infection fluctuated around an average of $65 \%$, with comparable values between 2001 and 2004 (range 62.5-69.2\%) and a significant drop (37.5\%) in 2005 (p < 0.015) (Fig. 1).

\section{Detection rate and temporal variation of gastrointestinal viral agents}

Figure 2 shows the detection rate for each single virus found in the stools of the 227 children studied from Valencia. EV was the most common etiological agent detected, present in 86 (37.9\%) of the 227 samples, followed by $\mathrm{HuCV}$ in 53 (23.3\%), HAdV in 26 (11.5\%), HAstV in 8 (3.5\%), KV in two (1.3\%) and AiV in one (0.4\%) (Fig. 2). No HPBV was detected.

As shown in Fig. 1, EV, $\mathrm{HuCV}$, and HAdV were detected throughout the study period, while the finding of HAstV, KV and AiV was intermittent (particularly $\mathrm{KV}$ and $\mathrm{AiV}$ that emerged at the last years). A significant decrease (from 53.8 to $18.8 \%, \mathrm{p}=0.0006$ ) in the detection rate for EV was observed between 2003 and 2005; a reduction was also observed for $\mathrm{HuCV}$ (from 29.2 to $10.4 \%, \mathrm{p}=0.021$ ) from 2004 to 2005 . No trend was observed for the other viruses (Fig. 1).

\section{Socio-demographic variables of all the children studied Age}

The median age of the 227 children studied was of 11 months (range 1-58). No significant difference was observed in the median age of the 134 virus infected children when compared with the 93 children who resulted negative for all viral agents studied (diarrhea of unknown etiology) (13 vs. 10 months, $\mathrm{p}=0.218$ ). For the children under 24 months of age, the proportion of positive samples for viruses was significantly higher than that of negative samples $(85.8 \%$ vs. $75.3 \%)(p=0.044)$ (Fig. 3a).

\section{Gender}

A predominance of male over female was observed among the children positive, as well as among those negative children for viral infection (Fig. 3b), and the differences within genders were not significant $(p>0.05)$.

\section{Socioeconomic level (Graffar)}

The proportion of children from the lowest socioeconomic level (Graffar 5) was significantly higher among the positive for viral detection than among those negative (47.8\% vs. $34.4 \%, \mathrm{p}=0.045$ ) (Fig. $3 \mathrm{c}$ ). 


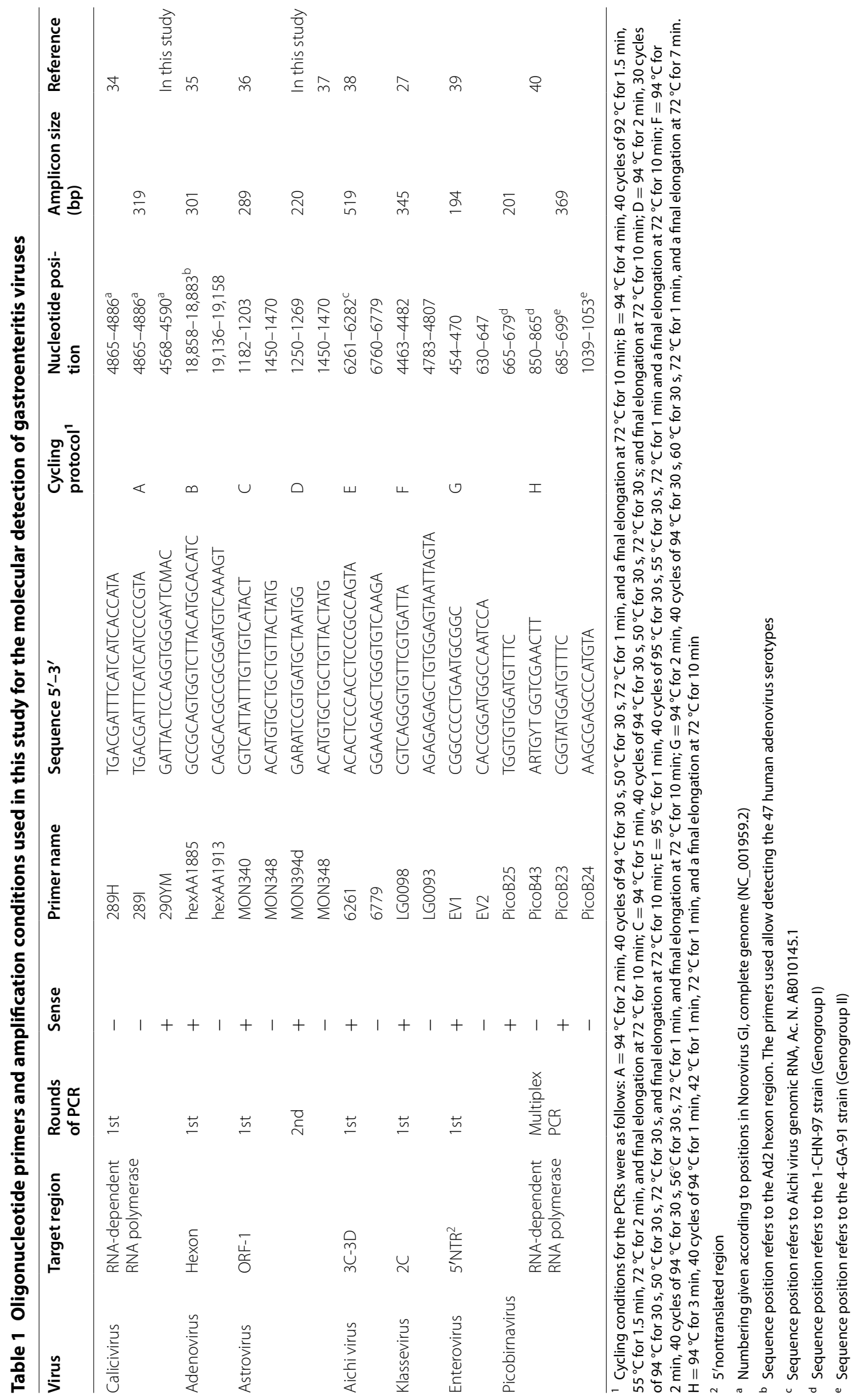



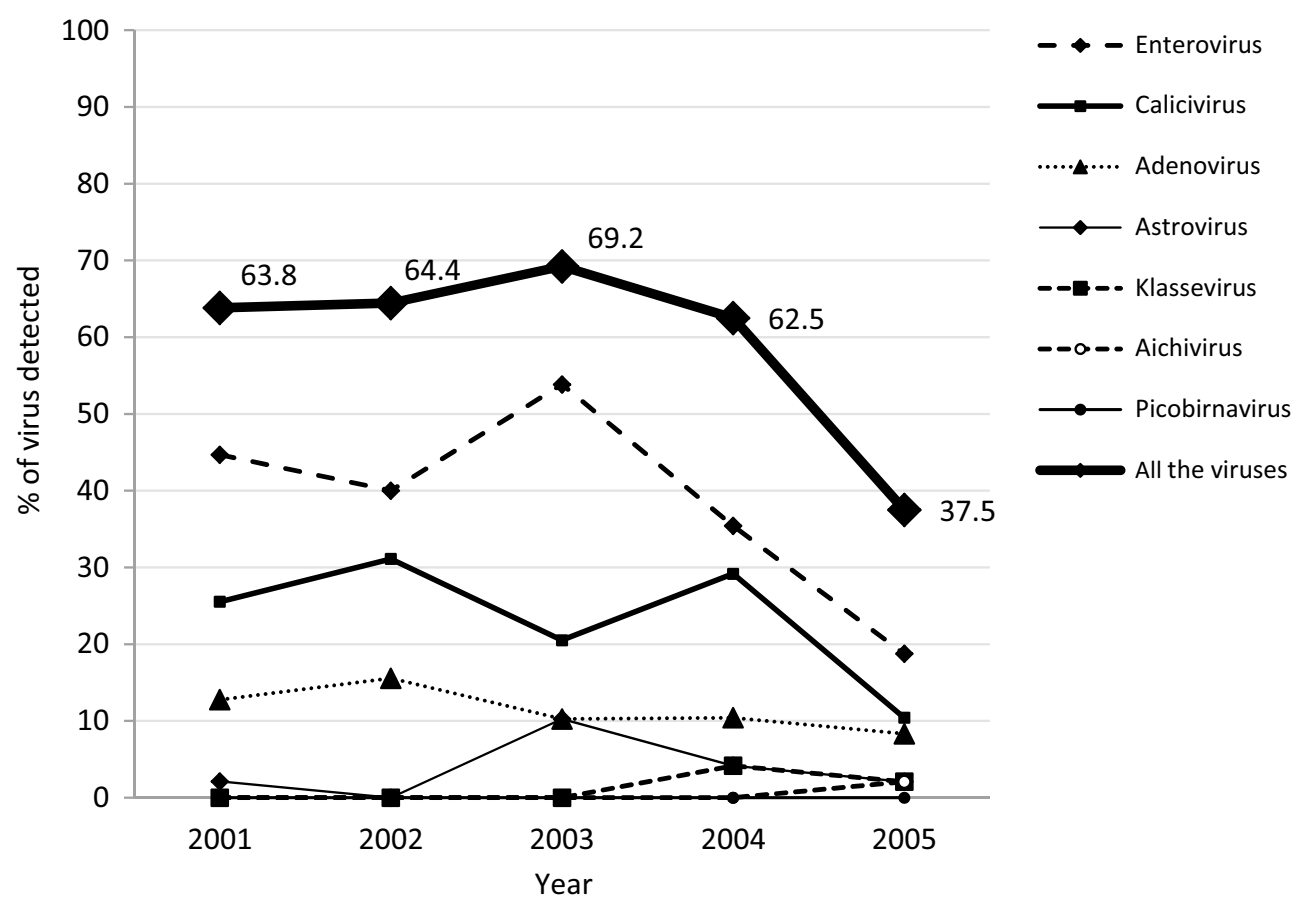

. 1 Temporal variation of the positivity rate for gastroenteritis viruses in children with diarrhea from Valencia, 2001-2005. The prevalence of viral infection among the 227 RV-negative children studied is indicated with the line marked with diamonds. A significant drop $(p<0.015)$ in the overall percentage of children infected was observed in 2005. The others drawn lines show the temporal detection rates for each single viral infection

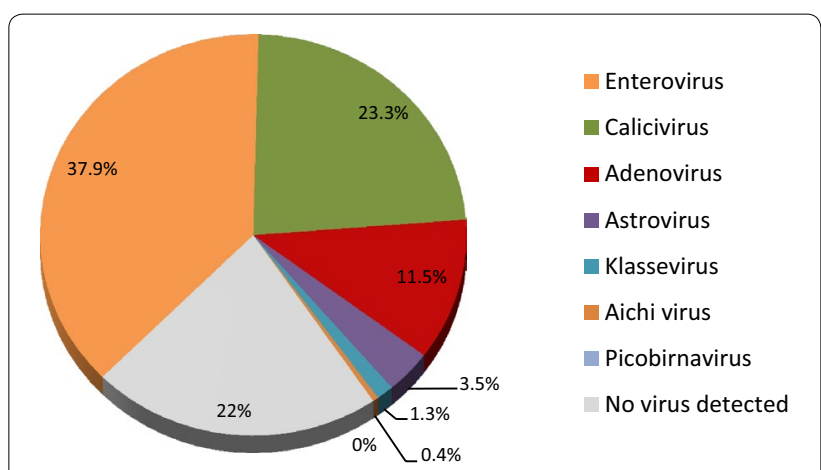

Fig. 2 Distribution (\%) of gastrointestinal viruses among 227 children with non-RV associated diarrhea from Valencia, 2001-2005

\section{Malnutrition status}

Well-nourished children prevailed over those with some condition of malnourishment; nevertheless, no statistical significant differences $(\mathrm{p}>0.05)$ were observed for infected or non-infected children in any status (Fig. 3d).

\section{Type of treatment}

The diarrhea caused by viruses was significantly more associated with outpatient episodes that did not require hospitalization than diarrhea episodes of unknown etiology, not caused by any of the viruses studied $(80.6 \%$ vs. $66.7 \%, \mathrm{p}=0.017$ ) (Fig. 3e).

\section{Dehydration}

The proportion of children who suffered a mild or severe form of dehydration was significantly lower among virus infected children than among children with no detectable virus ( $14.9 \%$ vs $28 \%, \mathrm{p}=0.016$ ) (Fig. $3 \mathrm{f}$ ).

\section{Incidence of single or mixed infection}

Of the 134 children with diarrhea caused for any of the viruses studied, $95(70.9 \%)$ resulted positive at a single enteric viral pathogen, and $39(29 \%)$ suffered a mixed infection or coinfection (simultaneous detection of two or more viruses) (Table 2). The analysis of the sociodemographic variables and clinical parameters in relation with the severity of the AGE between single and mixed infected children did not reveal any significant difference ( $p>0.05)$. Thus, age, gender, Graffar, nutritional status, dehydration and type of treatment of the children infected with a single virus were similar to those observed in children with coinfections (Table 2).

Figure 4 shows the proportion of gastrointestinal viruses involved in single or in coinfection during the AGE episodes. EVs were more frequently associated with single infection $(58 / 86$ strains detected, $67.4 \%, \mathrm{p}=0.003)$ 

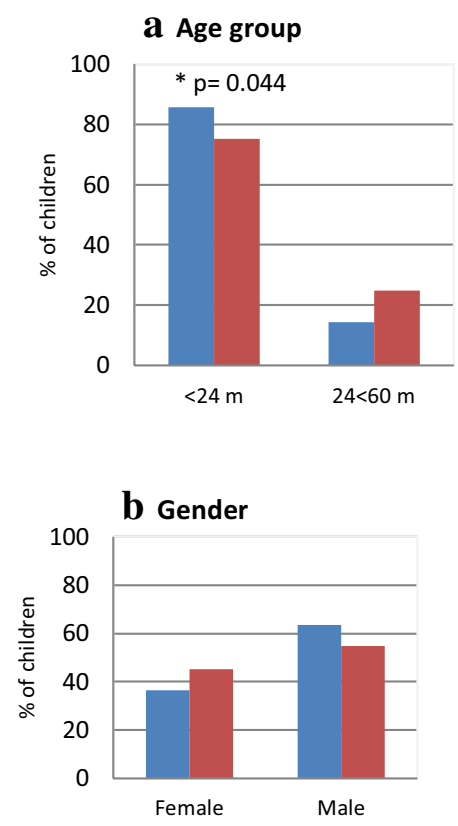

c Graffar

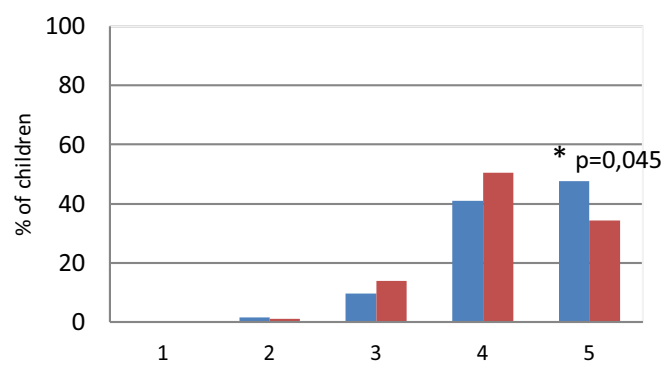

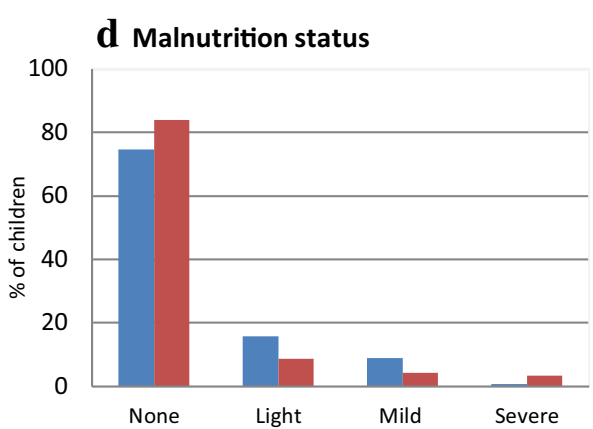

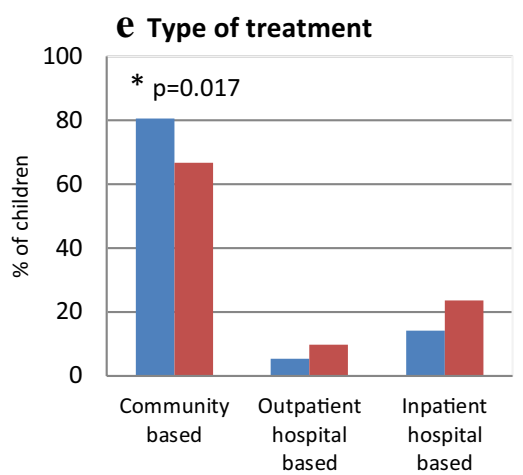

f Dehydration

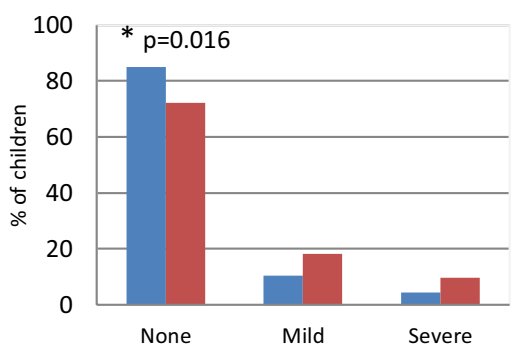

Fig. 3 Distribution (\%) of virus positive and negative children in according to demographic and clinical characteristics. A comparison between the proportion of children with viral infection ( $n=134$, histogram bars in blue color) and those without any virus detectable with the specific primers used in this study ( $n=93$, in red color) is shown. The variables shown are: a age group, b gender, c Graffar, $\mathbf{d}$ malnutrition status, $\mathbf{e}$ type of treatment, and $\mathbf{f}$ dehydration. Significant differences among groups are indicated with asterisk (*), including " $p$ " value

than the other viruses. In contrast, HAdVs were significantly more involved in coinfections $(18 / 26,69.2 \%$, $\mathrm{p}=0.011)$ than in single infections. Finally, for $\mathrm{HuCV}$ and HAstV more than half of the infections were coinfections (54.7 and 62.5\%, respectively) (Fig. 4).

The most frequent combination of coinfecting agents was given by $\mathrm{HuCV} / \mathrm{EV}$, which affected 15 of 39 children (38.5\%) (Table 3). HAdV coinfected especially with EV (17.9\%), HuCV (15.4\%), both together (10.3\%), or with HAstV (2.6\%) (Table 3), which represent altogether $46.2 \%$ of the 39 mixed infections evaluated in this study. The only AiV strain found in this study was detected in mixed infection with a strain of $\mathrm{HuCV}$ (Table 2) in a severely dehydrated and malnourished child of 1 month old, living in poor conditions (Graffar 5), who required to be hospitalized.

Socio-demographic and clinical features of the children according to the gastrointestinal virus detected.

Table 4 shows the comparison of the socio-demographic and clinical parameters for the 95 children presenting only single virus infection. The analysis excluded HAstV and KV because of the low number of samples positive.

No significant difference was shown in the median age, gender, Graffar and nutritional status of the children affected, regardless of the infecting virus. Children less than 24 months prevailed over the oldest, and although the EV infected subjects were slightly in a higher 
Table 2 Comparison of the demographic and clinical characteristics of children suffering single or mixed viral infections

\begin{tabular}{|c|c|c|}
\hline & Single infection & Mixed infection \\
\hline N. of children infected & $95(70.9)$ & $39(29.1)$ \\
\hline Median age, months & 13 & 11 \\
\hline \multicolumn{3}{|l|}{ Age group, months } \\
\hline$<24$ & $78(82.1)$ & $37(94.9)$ \\
\hline $24-60$ & $17(17.9)$ & $2(5.1)$ \\
\hline \multicolumn{3}{|l|}{ Gender } \\
\hline Female & $31(32.6)$ & $18(46.2)$ \\
\hline Male & $64(67.4)$ & $21(53.8)$ \\
\hline \multicolumn{3}{|c|}{ Graffar socioeconomic level, n. (\%) } \\
\hline 1 & - & - \\
\hline 2 & $1(1.1)$ & $1(2.6)$ \\
\hline 3 & $9(9.5)$ & $4(10.3)$ \\
\hline 4 & $39(41.1)$ & $16(41)$ \\
\hline 5 & $46(48.4)$ & $18(46.2)$ \\
\hline \multicolumn{3}{|l|}{ Malnutrition status } \\
\hline None & $73(76.8)$ & $28(71.8)$ \\
\hline Light & $13(13.7)$ & $7(17.9)$ \\
\hline Mild & $9(9.5)$ & $3(7.7)$ \\
\hline Severe & - & $1(2.6)$ \\
\hline \multicolumn{3}{|l|}{ Dehydration } \\
\hline None & $82(86.3)$ & $31(79.5)$ \\
\hline Mild & $10(10.5)$ & $5(12.8)$ \\
\hline Severe & $3(3.2)$ & $3(7.7)$ \\
\hline \multicolumn{3}{|l|}{ Type of treatment } \\
\hline Outpatient & $78(82.1)$ & $30(76.9)$ \\
\hline Inpatient & $17(17.9)$ & $9(23.1)$ \\
\hline
\end{tabular}

Data are $n(\%)$ of children studied. No significant difference $(p>0.05)$ related with these variables was observed. Data were analysed using $x^{2}$ or Fisher's exact test (two-tailed, 95\% confidence intervals) when the size sample was less than 5 (Epi Info ${ }^{\mathrm{TM}}$ 7.1.4.0, CDC Atlanta, GA, USA). The significance of the difference for the ages was calculated by Student's test. The scale used for the Graffar socioeconomic level was based in a modified methodology described by Méndez Castellano et al. [32]

percentage $(22.4 \%)$ when compared with those infected with $\mathrm{HuCV}$ and HAdV, the differences were not significant $(\mathrm{p}>0.05)$.

Regarding the variables related with the severity of the AGE, no virus was significantly associated with more severe dehydration or a greater number of inpatient episodes $(\mathrm{p}>0.05)$.

\section{Discussion}

The present study shows the epidemiology of viruses that caused pediatric AGE in Valencia (Venezuela) between 2001 and 2005 before the RV vaccine implementation. Although the population studied does not represent the entire epidemiological data of the viral diarrheal disease of this country, the results should provide a good

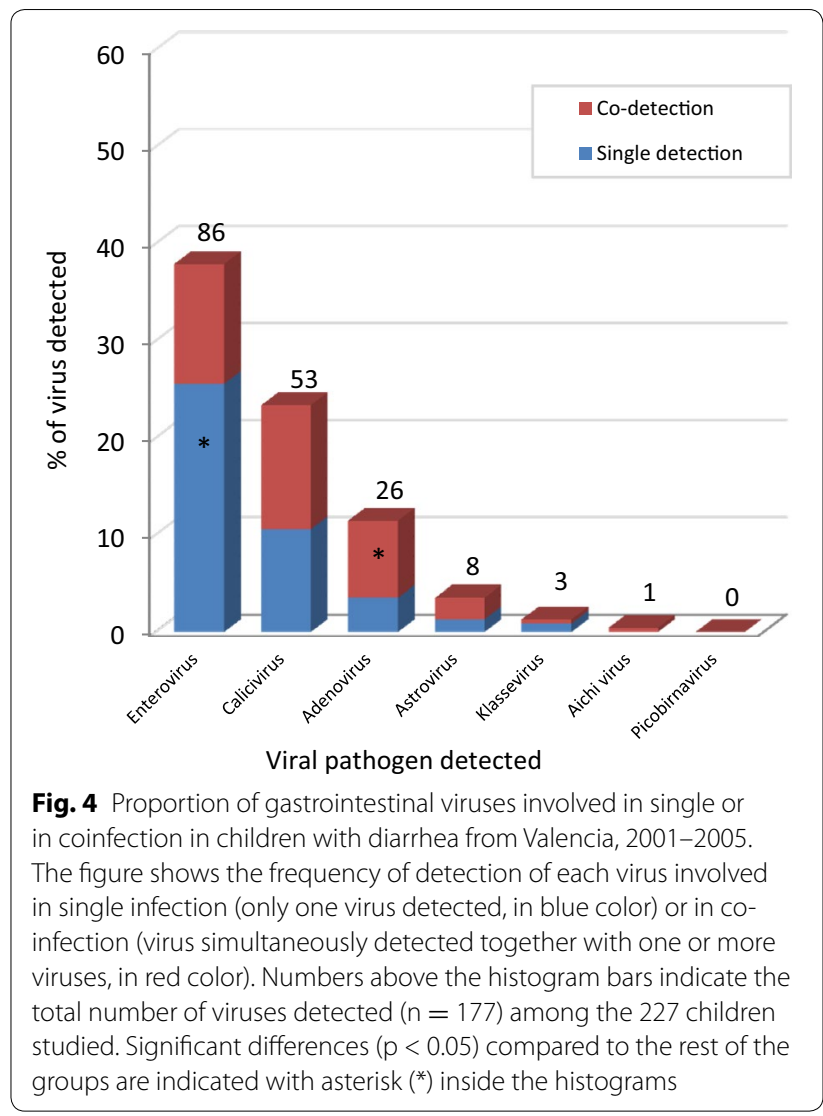

estimation of the real impact of the viral AGE during the years 2001-2005 by causes other than RV.

The high prevalence of enteric virus found in this study is similar to that reported previously by others authors [12, 41, 42], and showed that EV, HuCV, HAdV, HAstV, $\mathrm{AiV}$ and $\mathrm{KV}$ accounted for a significant proportion of RVnegative AGE in this locality. The rate was lower than that shown by a Japanese study where multiplex assays including a larger number of target pathogens were applied [8], but it was higher than that described in European, Asian and African studies [17, 43-45], as well as that reported in a previous study performed during the year 2003 in Valencia City [46]. Of note, a fraction (41\%) of the diarrhea cases here studied remained without a precise etiology, probably due to a low viral load, the presence of inhibitors in the samples or viruses not included in the assays. However, the relatively higher detection rate of viral agents reflects an increase of the diagnostic capabilities of the PCR-based assays used, although it could also depend on the population group studied, which included mostly children under 24 months of age, belonging to the lowest socioeconomic stratum (Graffar 5), living in the most precarious sanitary and dietary conditions, where the fecal-oral transmission of a wide range of pathogens was favored. 
Table 3 Viral agents involved in the 39 coinfections in children suffering diarrhea in Valencia, 2001-2005

\begin{tabular}{lc}
\hline Coinfection pattern & Number (\%) \\
\hline Calicivirus + Enterovirus & $15(38.5)$ \\
Enterovirus + Adenovirus & $7(17.9)$ \\
Calicivirus + Adenovirus & $6(15.4)$ \\
Calicivirus + Adenovirus + Enterovirus & $4(10.3)$ \\
Calicivirus + Astrovirus & $2(5.1)$ \\
Calicivirus + Klassevirus & $1(2.6)$ \\
Calicivirus + Aichi virus & $1(2.6)$ \\
Adenovirus + Astrovirus & $1(2.6)$ \\
Astrovirus + Enterovirus & $2(5.1)$ \\
\hline
\end{tabular}

The significant higher frequency of viral infections, as well coinfections, shown here in children less than 24 months of age contrasts with previous data from Valencia where no age differences were observed in viral enteric infections [46]. It is instead in agreement with data obtained by others authors elsewhere [44, 47], and shows the highest susceptibility of the children to the viral infection during the early childhood, perhaps due to unsatisfactory protective immunity.

Previous data have reported that viral infections other than RV are clinically milder than the RV infection [44, $46,48]$. In this study, only RV-negative stool samples were included; therefore a comparison of the clinical conditions with children infected with RV could not be done. However, the data suggest that the infections by viruses such as EV, HuCV, HAdV, HAstV, AiV and KV would be mainly associated with less severe diarrheic episodes, not necessarily demanding medical intervention or hospitalizations.

This study demonstrates the contribution of EV and $\mathrm{HuCV}$ as important etiologic agents of viral AGE in the setting studied, both viruses found together in mixed infections in almost a quarter of the cases studied. The detection rate obtained for $\mathrm{EV}$ as single infecting agent

Table 4 Demographic and clinical characteristics of the children with single infection

\begin{tabular}{|c|c|c|c|c|c|c|c|}
\hline & Enterovirus & Calicivirus & Adenovirus & Astrovirus & Klassevirus & Aichi virus & Picobirnavirus \\
\hline N. of children infected & 58 & 24 & 8 & 3 & 2 & 0 & 0 \\
\hline Median age, months & 14 & 11 & 8 & 13 & 0.6 & - & - \\
\hline \multicolumn{8}{|l|}{ Age group, months } \\
\hline$<24$ & 45 (77.6) & $21(87.5)$ & $7(87.5)$ & $3(100)$ & $2(100)$ & - & - \\
\hline $24-60$ & $13(22.4)$ & $3(12.5)$ & $1(12.5)$ & - & - & - & - \\
\hline \multicolumn{8}{|l|}{ Gender } \\
\hline Female & $16(27.6)$ & $9(37.5)$ & $3(37.5)$ & $2(66.7)$ & $1(50)$ & - & - \\
\hline Male & $42(72.4)$ & $15(62.5)$ & $5(62.5)$ & $1(33.3)$ & $1(50)$ & - & - \\
\hline \multicolumn{8}{|c|}{ Graffar socioeconomic level } \\
\hline 1 & - & - & - & - & - & - & - \\
\hline 2 & - & $1(4.2)$ & - & - & - & - & - \\
\hline 3 & $6(10.3)$ & $2(8.3)$ & $1(12.5)$ & - & - & - & - \\
\hline 4 & $21(36.2)$ & $11(45.8)$ & $4(50)$ & $1(33.3)$ & $2(100)$ & - & - \\
\hline 5 & $31(53.4)$ & $10(41.7)$ & $3(37.5)$ & $2(66.7)$ & - & - & - \\
\hline \multicolumn{8}{|l|}{ Malnutrition status } \\
\hline None & $43(74.1)$ & $18(75.0)$ & $8(100)$ & $2(66.7)$ & $2(100)$ & - & - \\
\hline Light & $7(12.1)$ & $5(20.8)$ & - & $1(33.3)$ & - & - & - \\
\hline Mild & $8(13.8)$ & $1(4.2)$ & - & - & - & - & - \\
\hline Severe & - & - & - & - & - & - & - \\
\hline \multicolumn{8}{|l|}{ Dehydration } \\
\hline None & $51(87.9)$ & $22(91.7)$ & $5(62.5)$ & $3(100)$ & $1(50)$ & - & - \\
\hline Mild & $6(10.3)$ & $1(4.2)$ & $3(37.5)$ & - & - & - & - \\
\hline Severe & $1(1.7)$ & $1(4.2)$ & - & - & $1(50)$ & - & - \\
\hline \multicolumn{8}{|l|}{ Type of treatment } \\
\hline Outpatient & 49 (84.5) & $20(83.3)$ & $5(62.5)$ & $3(100)$ & $1(100)$ & - & - \\
\hline Inpatient & $9(15.5)$ & $4(16.7)$ & $3(37.5)$ & - & - & - & - \\
\hline
\end{tabular}

Data are $\mathrm{n}(\%)$ of children studied. No significant difference $(\mathrm{p}>0.05)$ related with these variables was observed. Data were analysed using $x^{2}$ or Fisher's exact test (two-tailed, 95\% confidence intervals) when the size sample was less than 5 (Epi Info ${ }^{\mathrm{TM}}$ 7.1.4.0, CDC Atlanta, GA, USA). The significance of the difference for the ages was calculated by Student's test. The scale used for the Graffar socioeconomic level was based in a modified methodology described by Méndez Castellano et al. [32] 
was similar to that reported in a study carried out in Maracaibo (Venezuela) during 2008-2009 [49], and it was higher than that described in Thailand [23]. On the other hand, this rate was similar to the RV rate detection (24.5\%) reported in another study carried out in Valencia City, during the same period [33]. Some serotypes of echovirus and coxsackievirus $B$ have been described to be cause of diarrhea $[50,51]$. It is noteworthy that the presence of Sabin vaccine-related strains in stool samples of diarrheic children could have caused an overestimation in the EV detection rate with the PCR assay used. In addition, EVs could be occasionally shed with the feces of patients suffering a broad spectrum of other non-enteric diseases, sometimes in prolonged way $[20,23,50]$. This would explain in part the relatively higher rate of EV found in this study in infected children older than 24 months than that of other viruses. Thus, case-control studies and further genotyping of the strains detected will be desirable, to better define the burden of EV as a cause of diarrheal disease.

The overall prevalence of $\mathrm{HuCV}$ observed in this study, the second most common causative agent of viral AGE, was comparable to that described by others among RV-negative samples from children with diarrhea in four distinct Thai regions under sentinel surveillance between 2006 and 2008 [52], and higher than that reported previously in Valencia City during the 2003 [46]. This prevalence indicates a greater ability of the primers used in the PCR assay to detect a broad diversity of strains. It ratifies also the need of monitoring the contribution of the $\mathrm{HuCV}$ s to the burden of the AGE after implementation of RV vaccination.

A significant observation in this study was also the relatively higher detection rate of HAdV infection, as compared to a previous study based on serologic assays from Valencia [46], and to reports from other continents [5355 ] that suggest the existence of a geographic variability of the virus prevalence, as well as the important contribution of the HAdVs to the mixed infections. A similar rate of HAdV detection was reported from Korea during the years 2012-2013 [6], but it is noteworthy that the relative high prevalence for HAdV observed in this study could have also been determined by the presence in the stools of non-enteric types that could occasionally be excreted from respiratory source, and detected by the assay used, directed to amplify a conserved portion of the hexoncoding gene, common for all the HAdV. Thus, the molecular characterization is a crucial step to define the species of HAdV mainly involved in diarrhea and to understand the true contribution to the AGE. No information about the types of HAdV that have been circulating in Venezuela is available, but preliminary results indicate that most of the HAdV strains found in Valencia City during the same period were enteric types (Blanco R., personal communication).
HAstV were involved in a modest number of episodes, mainly in mixed infections with $\mathrm{HuCV}, \mathrm{HAdV}$ and $\mathrm{EV}$, which evolved as a mild form of AGE, similar to that reported by other studies [17, 41]. The HAstV detection rate found here was comparable with the data from a previous local study [46], and those from Lebanon, France and Germany [41, 44, 56].

Although AiV and KV have been associated with AGE in several continents [17, 24, 27, 28, 57-59], to our knowledge, there have not been reports of AiV and KV causing infections in Venezuelan human population. Unfortunately, the low rate of detection in this study did not allow to evaluate their relationship with socio-demographic and clinic variables, but their presence confirms the participation as agent of childhood diarrhea and the relatively recent introduction in Venezuela.

In this study were used primers directed to the most commonly described HPBVs of genogroup I and II [40], but no virus was found. Possibly, their high genomic diversity could have limited the detection with the RTPCR assay available. Thus, additional efforts are required to optimize assays able to identify these and other uncommon viruses associated with AGE, as well the use of new technologies as virus microarray, sequence-independent amplification and sequencing of viral nucleic acids $[7,11,22]$, to clarify their epidemiology and possible pathogenicity.

\section{Conclusions}

This study demonstrated a high prevalence of enteropathogenic viruses other than RV in Venezuelan children suffering acute diarrhea, confirming the contribution of conventional enteric viruses in the pediatric AGE in this country. In addition, the presence of emergent viruses more recently described, such as $\mathrm{AiV}$ and $\mathrm{KV}$ is also described. Because the study included only diarrheic pediatric patients who received medical attention in Valencia City, the prevalence of virus infection reported here could represent an underestimation of the true rates of gastroenteritis associated viruses circulation in the population. Future studies should consider asymptomatic and self-limiting diarrhea cases. However, these results, obtained from five consecutive years, expand the knowledge about the spectrum of viral agents involved in acute community-acquired disease, and provide a baseline data for the molecular epidemiology study of these pathogens, which will be helpful for comparison with regional data obtained in post-RV vaccination era. Finally, they ratify the need for a long-term surveillance for such enteropathogenic viruses, following the implementation of RV vaccination, to better understand the participation of these agents in children AGE. 


\begin{abstract}
Abbreviations
RT-PCR: reverse transcriptase polymerase chain reaction; AGE: acute gastroenteritis; RV: rotavirus; HuCV: human calicivirus; HAdV: human adenovirus; HAstV: human astrovirus; HPBV: human picobirnavirus; HBoV: human bocavirus; KV: klassevirus/salivirus; AiV: Aichi virus; EV: enteroviruses; CHET: Ciudad Hospitalaria "Dr. Enrique Tejera"; IVIC: Instituto Venezolano de Investigaciones Científicas; MMLV: Moloney Murine Leukemia Virus; cDNA: complementary DNA; WHO: World Health Organization.
\end{abstract}

\section{Authors' contributions}

EV and ACA conceived the study, participated in the design/adaptation of experimental protocols, analysis results and wrote the initial draft of the manuscript. RG, ACA and RB were engaged in sample processing and data collection. EV supervised the laboratory procedures and PCR quality control, performed the statistical analysis, data interpretation, graphic representations of the results, and drafted the final manuscript. ACA, KP and RB performed the molecular analysis. ACA, RB, RG, JEL and FL helped reviewing the manuscript. All authors read and approved the final manuscript.

\begin{abstract}
Author details
${ }^{1}$ Laboratorio de Biología de Virus, Centro de Microbiología y Biología Celular, Instituto Venezolano de Investigaciones Científicas (IVIC), Apdo. 21827, Caracas 1020, Venezuela. ${ }^{2}$ Instituto Autónomo de Biomedicina Dr. Jacinto Convit-MPPS, Caracas, Venezuela. ${ }^{3}$ Departamento de Infectómica y Patogénesis Molecular, Centro de Investigación y Estudios Avanzados del Instituto Politécnico Nacional, Mexico, D.F., Mexico. ${ }^{4}$ Present Address: Departamento de Medicina Molecular y Bioprocesos, Instituto de Biotecnología, Universidad Nacional Autónoma de México (UNAM), Mexico, D.F., Mexico.
\end{abstract}

\section{Acknowledgements}

The authors are in debt with the infants and their families who participated in this study. We would like to thank the staff members and physicians of the CHET involved in this study, whom were engaged to sample and data collection, and Francesca Pagano for the HPBV testing at the Laboratorio de Biología de Virus (IVIC).

\section{Competing interests}

The authors declare that they have no competing interests.

\section{Availability of data and materials}

Data of the study can be available upon request from the corresponding author (EV).

\section{Ethics approval and consent to participate}

The study was approved by the ethical review committee of the IVIC. Informed written consent was obtained from the parents/guardians of the subjects before collecting the stool samples.

\section{Funding}

This study was partially supported by Grant LOCTI (Total Venezuela, C.A.) n. 2011000904 and by regular funds from the Instituto Venezolano de Investigaciones Científicas (IVIC), Venezuela.

\section{Publisher's Note}

Springer Nature remains neutral with regard to jurisdictional claims in published maps and institutional affiliations.

Received: 14 December 2017 Accepted: 18 February 2018

Published online: 22 February 2018

\section{References}

1. Liu L, Oza S, Hogan D, Chu Y, Perin J, Zhu J, Lawn JE, Cousens S, Mathers C, Black RE. Global, regional, and national causes of under-5 mortality in 2000-15: an updated systematic analysis with implications for the sustainable development goals. Lancet. 2016;388:3027-35. https://doi. org/10.1016/S0140-6736(16)31593-8.
2. GBD Diarrhoeal Diseases Collaborators. Estimates of global, regional, and national morbidity, mortality, and aetiologies of diarrhoeal diseases: a systematic analysis for the Global Burden of Disease Study 2015. Lancet Infect Dis. 2017;17:909-48. https://doi.org/10.1016/ S1473-3099(17)30276-1.

3. Black RE, Cousens S, Johnson HL, Lawn JE, Rudan I, Bassani DG, Jha P, Campbell H, Walker CF, Cibulskis R, Eisele T, Liu L, Mathers C, Child Health Epidemiology Reference Group of WHO and UNICEF. Global, regional, and national causes of child mortality in 2008: a systematic analysis. Lancet. 2010;375:1969-87. https://doi.org/10.1016/S0140-6736(10)60549-1.

4. Tate JE, Burton AH, Boschi-Pinto C, Steele AD, Duque J, Parashar UD, WHO coordinated Global Rotavirus Surveillance Network. 2008 estimate of worldwide rotavirus-associated mortality in children younger than 5 years before the introduction of universal rotavirus vaccination programmes: a systematic review and meta-analysis. Lancet Infect Dis. 2012;2012(12):136-41.

5. Lanata CF, Fischer-Walker CL, Olascoaga AC, Torres CX, Aryee MJ, Black RE, Child Health Epidemiology Reference Group of the World Health Organization and UNICEF. Global causes of diarrheal disease mortality in children < 5 years of age: a systematic review. PLoS ONE. 2013;8(9):e72788. https://doi.org/10.1371/journal.pone.0072788.

6. Kim A, Chang JY, Shin S, Yi H, Moon JS, Ko JS, Oh S. Epidemiology and factors related to clinical severity of acute gastroenteritis in hospitalized children after the introduction of rotavirus vaccination. J Korean Med Sci. 2017;32:465-74. https://doi.org/10.3346/jkms.2017.32.3.465.

7. Spina A, Kerr KG, Cormican M, Barbut F, Eigentler A, Zerva L, Tassios P, Popescu GA, Rafila A, Eerola E, Batista J, Maass M, Aschbacher R, Olsen KE, Allerberger F. Spectrum of enteropathogens detected by the FilmArray Gl Panel in a multicentre study of community-acquired gastroenteritis. Clin Microbiol Infect. 2015;21:719-28. https://doi.org/10.1016/j. cmi.2015.04.007.

8. Thongprachum A, Khamrin P, Pham NT, Takanashi S, Okitsu S, Shimizu H, Maneekarn N, Hayakawa S, Ushijima H. Multiplex RT-PCR for rapid detection of viruses commonly causing diarrhea in pediatric patients. J Med Virol. 2017;89:818-24. https://doi.org/10.1002/jmv.24711.

9. Vizzi E, Piñeros OA, Oropeza MD, Naranjo L, Suárez JA, Fernández R, Zambrano JL, Celis A, Liprandi F. Human rotavirus strains circulating in Venezuela after vaccine introduction: predominance of G2P[4] and reemergence of G1P[8]. Virol J. 2017;14:58. https://doi.org/10.1186/ s12985-017-0721-9.

10. Simpson R, Aliyu S, Iturriza-Gómara M, Desselberger U, Gray J. Infantile viral gastroenteritis: on the way to closing the diagnostic gap. J Med Virol. 2003;70:258-62.

11. Liu Y, Xu ZQ, Zhang Q, Jin M, Yu JM, Li JS, Liu N, Cui SX, Kong XY, Wang $\mathrm{H}$, Li HY, Cheng WX, Duan ZJ. Simultaneous detection of seven enteric viruses associated with acute gastroenteritis by a multiplexed luminexbased assay. J Clin Microbiol. 2012;50:2384-9. https://doi.org/10.1128/ JCM.06790-11.

12. Valentini D, Vittucci AC, Grandin A, Tozzi AE, Russo C, Onori M, Menichella D, Bartuli A, Villani A. Coinfection in acute gastroenteritis predicts a more severe clinical course in children. Eur J Clin Microbiol Infect Dis. 2013;32:909-15. https://doi.org/10.1007/s10096-013-1825-9.

13. Koh H, Baek SY, Shin Jl, Chung KS, Jee YM. Coinfection of viral agents in Korean children with acute watery diarrhea. J Korean Med Sci. 2008;23:937-40. https://doi.org/10.3346/jkms.2008.23.6.937.

14. Glass RI, Bresee J, Jiang B, Gentsch J, Ando T, Fankhauser R, Noel J, Parashar U, Rosen B, Monroe SS. Gastroenteritis viruses: an overview. vol. 38. In: Novartis Found Symposium 238; New York: Wiley; 2001. p. 5-19. (discussion 19-25).

15. Wilhelmi I, Roman E, Sánchez-Fauquier A. Viruses causing gastroenteritis. Clin Microbiol Infect. 2003;9:247-62.

16. De Benedictis P, Schultz-Cherry S, Burnham A, Cattoli G. Astrovirus infections in humans and animals - molecular biology, genetic diversity, and interspecies transmissions. Infect Genet Evol. 2011;11:1529-44.

17. Sdiri-Loulizi K, Gharbi-Khélifi H, de Rougemont A, Chouchane S, Sakly N, Ambert-Balay K, Hassine M, Guédiche MN, Aouni M, Pothier P. Acute infantile gastroenteritis associated with human enteric viruses in Tunisia. J Clin Microbiol. 2008;46:1349-55. https://doi.org/10.1128/JCM.02438-07.

18. Jiang H, Holtz LR, Bauer I, Franz CJ, Zhao G, Bodhidatta L, Shrestha SK, Kang G, Wang D. Comparison of novel MLB-clade, VA-clade and classic 
human astroviruses highlights constrained evolution of the classic human astrovirus nonstructural genes. Virology. 2013;436:8-14.

19. Ouédraogo N, Kaplon J, Bonkoungou IJ, Traoré AS, Pothier P, Barro N Ambert-Balay K. Prevalence and genetic diversity of enteric viruses in children with diarrhea in Ouagadougou, Burkina Faso. PLoS ONE. 2016;19(11):e0153652. https://doi.org/10.1371/journal.pone.0153652.

20. Pham NT, Trinh QD, Chan-It W, Khamrin P, Shimizu H, Okitsu S, Mizuguchi M, Ushijima H. A novel RT-multiplex PCR for detection of Aichi virus, human parechovirus, enteroviruses, and human bocavirus among infants and children with acute gastroenteritis. J Virol Methods. 2010;169:193-7. https://doi.org/10.1016/j.jviromet.2010.07.038.

21. Yamashita T, Kobayashi S, Sakae K, Nakata S, Chiba S, Ishihara Y, Isomura S. Isolation of cytopathic small round viruses with BS-C-1 cells from patients with gastroenteritis. J Infect Dis. 1991;164:954-7.

22. Holtz L, Finkbeiner S, Zhao G, Kirkwood C, Girones R, Pipas J, Wang D. Klassevirus 1, a previously undescribed member of the family Picornaviridae, is globally widespread. Virol J. 2009;6:86. https://doi. org/10.1186/1743-422X-6-86.

23. Chansaenroj J, Tuanthap S, Thanusuwannasak T, Duang-In A, Klinfueng S, Thaneskongtong N, Vutithanachot V, Vongpunsawad S, Poovorawan Y. Human enteroviruses associated with and without diarrhea in Thailand between 2010 and 2016. PLoS ONE. 2017;27(12):e0182078. https://doi. org/10.1371/journal.pone.0182078.

24. Ambert-Balay K, Lorrot M, Bon F, Giraudon H, Kaplon J, Wolfer M, Lebon P, Gendrel D, Pothier P. Prevalence and genetic distribution of Aichi virus strains in stool samples from community and hospitalized patients. J Clin Microbiol. 2008;46:1252-8.

25. Alcalá A, Vizzi E, Rodríguez-Díaz J, Zambrano JL, Betancourt W, Liprandi F. Molecular detection and characterization of Aichi viruses in sewagepolluted waters of Venezuela. Appl Environ Microbiol. 2010;76:4113-5.

26. Li L, Victoria J, Kapoor A, Blinkova O, Wang C, Babrzadeh F, Mason CJ, Pandey P, Triki H, Bahri O, Oderinde BS, Baba MM, Bukbuk DN, Besser JM, Bartkus JM, Delwart EL. A novel picornavirus associated with gastroenteritis. J Virol. 2009;83:12002-6. https://doi.org/10.1128/JVI.01241-09.

27. Han TH, Kim CH, Chung JY, Park SH, Hwang ES. Klassevirus infection in children, South Korea. Emerg Infect Dis. 2010;16:1623-5. https://doi. org/10.3201/eid1610.100539.

28. Itta KC, Patil T, Kalal S, Ghargi KV, Roy S. Salivirus in children with diarrhoea, western India. Int J Infect Dis. 2016;52:14-5. https://doi.org/10.1016/j. ijid.2016.09.015.

29. Salinas B, González G, González R, Escalona M, Materán M, Pérez-Schael I. Epidemiologic and clinical characteristics of rotavirus disease during five years of surveillance in Venezuela. Pediatr Infect Dis J. 2004;23:S161-7.

30. World Health Organization (WHO). A manual for the treatment of diarrhea: for use by physicians and other senior health workers. Geneva: World Health Organization; 2005.

31. O'Ryan ML, et al. Rotavirus-associated medical visits and hospitalizations in South America: a prospective study at three large sentinel hospitals. Pediatr Infect Dis J. 2001;20:685-93.

32. Méndez-Castellano H, De Méndez MC. Estratificación social y biología humana: método Graffar modificado. Arch Venez Pueric Pediatr. 1986;49:93-104

33. González R, Rivero L. Genetic diversity of rotavirus group a: correlation between $\mathrm{G} 3$ type and severity of the infection, Valencia, Venezuela. Invest Clin. 2013;54:34-46.

34. Farkas T, Zhong WM, Jing Y, Huang PW, Espinosa SM, Martinez N, Morrow AL, Ruiz-Palacios GM, Pickering LK, Jiang X. Genetic diversity among sapoviruses. Arch Virol. 2004;149:1309-23.

35. Allard A, Girones R, Juto P, Wadell G. Polymerase chain reaction for detection of adenoviruses in stool samples. J Clin Microbiol. 1990;28:2659-67.

36. Belliot $\mathrm{G}$, Laveran $\mathrm{H}$, Monroe SS. Detection and genetic differentiation of human astroviruses: phylogenetic grouping varies by coding region. Arch Virol. 1997;142:1323-34.

37. Belliot GM, Fankhauser RL, Monroe SS. Characterization of "Norwalk-like viruses" and astroviruses by liquid hybridization assay. J Virol Methods. 2001:91:119-30

38. Yamashita T, Sugiyama M, Tsuzuki H, Sakae K, Suzuki Y, Miyazaki Y. Application of a reverse transcription-PCR for identification and differentiation of Aichi virus, a new member of the Picornavirus family associated with gastroenteritis in humans. J Clin Microbiol. 2000;38:2955-61.
39. Shen S, Desselberger U, McKee TA. The development of an antigen capture polymerase chain reaction assay to detect and type human enteroviruses. J Virol Methods. 1997;65:139-44.

40. Rosen BI, Fang ZY, Glass RI, Monroe SS. Cloning of human picobirnavirus genomic segments and development of an RT-PCR detection assay. Virology. 2000;25(277):316-29.

41. Oh DY, Gaedicke G, Schreier E. Viral agents of acute gastroenteritis in German children: prevalence and molecular diversity. J Med Virol. 2003;71:82-93.

42. Lekana-Douki SE, Kombila-Koumavor C, Nkoghe D, Drosten C, Drexler JF, Leroy EM. Molecular epidemiology of enteric viruses and genotyping of rotavirus A, adenovirus and astrovirus among children under 5 years old in Gabon. Int J Infect Dis. 2015;34:90-5. https://doi.org/10.1016/j. ijid.2015.03.009.

43. Colomba C, De Grazia S, Giammanco GM, Saporito L, Scarlata F, Titone L, Arista S. Viral gastroenteritis in children hospitalised in Sicily, Italy. Eur J Clin Microbiol Infect Dis. 2006;25:570-5.

44. Marie-Cardin A, Gourlain K, Mouterde O, Castignolles N, Hellot MF, Mallet $\mathrm{E}$, Buffet-Janvresse C. Epidemiology of acute viral gastroenteritis in children hospitalized in Rouen, France. Clin Infect Dis. 2002:34:1170-8.

45. Ouyang Y, Ma H, Jin M, Wang X, Wang J, Xu L, Lin S, Shen Z, Chen Z, Qiu Z, Gao Z, Peng L, Li J. Etiology and epidemiology of viral diarrhea in children under the age of five hospitalized in Tianjin, China. Arch Virol. 2012;157:881-7. https://doi.org/10.1007/s00705-012-1235-9.

46. González GG, Liprandi F, Ludert JE. Molecular epidemiology of enteric viruses in children with sporadic gastroenteritis in Valencia, Venezuela. J Med Virol. 2011;83:1972-82.

47. Thongprachum A, Takanashi S, Kalesaran AF, Okitsu S, Mizuguchi M, Hayakawa S, Ushijima H. Four-year study of viruses that cause diarrhea in Japanese pediatric outpatients. J Med Virol. 2015;87:1141-8. https://doi. org/10.1002/jmv.24155.

48. Pang XL, Honma S, Nakata S, Vesikari T. Human caliciviruses in acute gastroenteritis of young children in the community. J Infect Dis. 2000;181(Suppl 2):S288-94.

49. Wildermann N, Porto-Espinoza L, Moronta R, Bracho M, Costa L, Callejas D. Detección molecular mediante RT PCR de calicivirus y enterovirus en niños menores de 6 años con síndrome diarreico. Rev Soc Ven Microbiol. 2010;2010(30):1-8.

50. Zhou HT, Yi HS, Guo YH, Pan YX, Tao SH, Wang B, Chen MJ, Yang M, Yu N. Enterovirus-related diarrhoea in Guangdong, China: clinical features and implications in hand, foot and mouth disease and herpangina. BMC Infect Dis. 2016;16:128. https://doi.org/10.1186/s12879-016-1463-9.

51. Holtz LR, Cao S, Zhao G, Bauer IK, Denno DM, Klein EJ, Antonio M, Stine OC, Snelling TL, Kirkwood CD, Wang D. Geographic variation in the eukaryotic virome of human diarrhea. Virology. 2014;468-470:556-64. https://doi.org/10.1016/j.virol.2014.09.012.

52. Pongsuwanna Y, Tacharoenmuang R, Prapanpoj M, Sakon N, Komoto S, Guntapong R, Taniguchi K. Monthly distribution of norovirus and sapovirus causing viral gastroenteritis in Thailand. Jpn J Infect Dis. 2017;24(70):84-6. https://doi.org/10.7883/yoken.JJID.2015.440.

53. Chhabra P, Payne DC, Szilagyi PG, Edwards KM, Staat MA, Shirley SH, Wikswo M, Nix WA, Lu X, Parashar UD, Vinjé J. Etiology of viral gastroenteritis in children $<5$ years of age in the United States, 2008-2009. J Infect Dis. 2013;208:790-800. https://doi.org/10.1093/infdis/jit254.

54. Rovida F, Campanini G, Piralla A, Adzasehoun KM, Sarasini A, Baldanti F. Molecular detection of gastrointestinal viral infections in hospitalized patients. Diagn Microbiol Infect Dis. 2013;77:231-5. https://doi. org/10.1016/j.diagmicrobio.2013.07.020.

55. Dey SK, Shimizu H, Phan TG, Hayakawa Y, Islam A, Salim AF, Khan AR, Mizuguchi M, Okitsu S, Ushijima H. Molecular epidemiology of adenovirus infection among infants and children with acute gastroenteritis in Dhaka City, Bangladesh. Infect Genet Evol. 2009;9:518-22. https://doi. org/10.1016/j.meegid.2009.02.001.

56. Zaraket H, Abou-El-Hassan H, Kreidieh K, Soudani N, Ali Z, Hammadi M, Reslan L, Ghanem S, Hajar F, Inati A, Rajab M, Fakhouri H, Ghanem B, Baasiri G, Melhem NM, Dbaibo G. Characterization of astrovirus-associated gastroenteritis in hospitalized children under five years of age. Infect Genet Evol. 2017;53:94-9. https://doi.org/10.1016/j.meegid.2017.05.016.

57. Pham NT, Khamrin P, Nguyen TA, Kanti DS, Phan TG, Okitsu S, Ushijima $H$. Isolation and molecular characterization of Aichi viruses from fecal 
specimens collected in Japan, Bangladesh, Thailand, and Vietnam. J Clin Microbiol. 2007:45:2287-8.

58. Oh DY, Oh DY, Silva PA, Hauroeder B, Diedrich S, Cardoso DD, Schreier E. Molecular characterization of the first Aichi viruses isolated in Europe and in South America. Adv Virol. 2006;151:1199-206.
59. Chuchaona W, Khamrin P, Yodmeeklin A, Kumthip K, Saikruang W, Thongprachum A, Okitsu S, Ushijima H, Maneekarn N. Detection and characterization of Aichi virus 1 in pediatric patients with diarrhea in Thailand. J Med Virol. 2017;89:234-8. https://doi.org/10.1002/jmv.24630.
Submit your next manuscript to BioMed Central and we will help you at every step:

- We accept pre-submission inquiries

- Our selector tool helps you to find the most relevant journal

- We provide round the clock customer support

- Convenient online submission

- Thorough peer review

- Inclusion in PubMed and all major indexing services

- Maximum visibility for your research

Submit your manuscript at www.biomedcentral.com/submit
() Biomed Central 